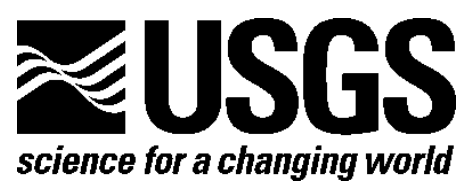

Prepared in cooperation with the New York State Department of Environmental Conservation

\title{
Groundwater-Level Analysis of Selected Wells in the Hoosic River Valley Near Hoosick Falls, New York, for Aquifer Framework and Properties
}

By John H. Williams and Paul M. Heisig

Open-File Report 2018-1015

U.S. Department of the Interior

U.S. Geological Survey 


\section{U.S. Department of the Interior \\ RYAN K. ZINKE, Secretary}

\section{U.S. Geological Survey \\ William H. Werkheiser, Deputy Director \\ exercising the authority of the Director}

U.S. Geological Survey, Reston, Virginia: 2018

For more information on the USGS-the Federal source for science about the Earth, its natural and living resources, natural hazards, and the environment-visit https://www.usgs.gov/ or call 1-888-ASK-USGS (1-888-275-8747).

For an overview of USGS information products, including maps, imagery, and publications, visit https://store.usgs.gov/.

Any use of trade, firm, or product names is for descriptive purposes only and does not imply endorsement by the U.S. Government.

Although this information product, for the most part, is in the public domain, it also may contain copyrighted materials as noted in the text. Permission to reproduce copyrighted items must be secured from the copyright owner.

Suggested citation:

Williams, J.H., and Heisig, P.M., 2018, Groundwater-level analysis of selected wells in the Hoosic River Valley near Hoosick Falls, New York, for aquifer framework and properties: U.S. Geological Survey Open-File Report 2018-1015, 14 p., https://doi.org/10.3133/ofr20181015. 


\section{Acknowledgments}

We thank the residents and commercial companies who graciously allowed access to their wells. This study would not have been possible without their cooperation. Special thanks to Kenneth Facin and Paul Baker of the Hoosick Falls Central School District for allowing access to the high school well and for their support in establishing the network of residential and commercial wells. 


\section{Contents}

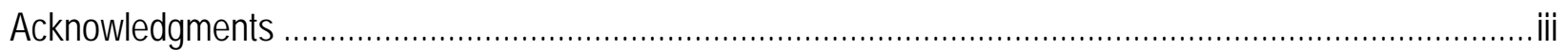

Abstract

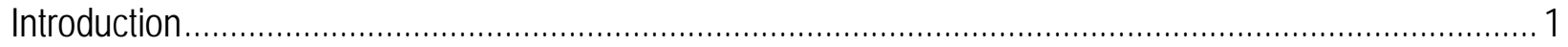

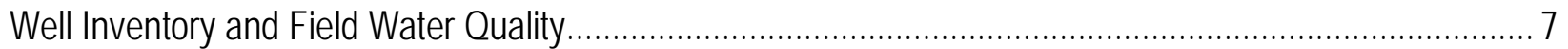

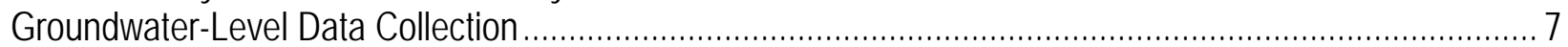

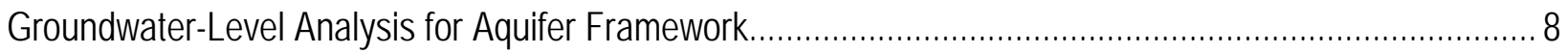

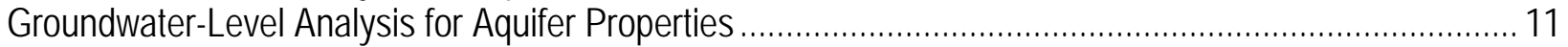

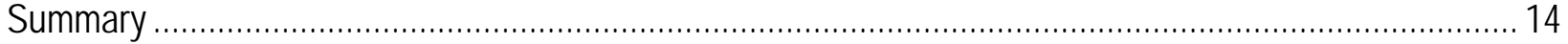

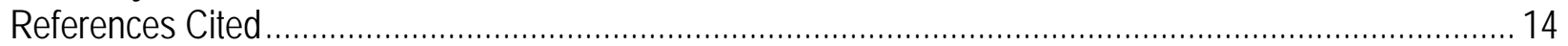

\section{Figures}

1. Map showing surficial geology of the study area and location of selected wells in the Hoosic River

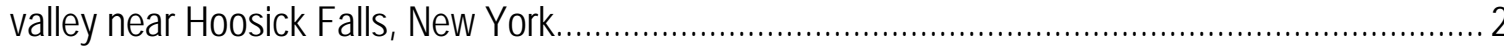

2. Diagram showing geologic section of the study area, Hoosic River valley, Hoosick Falls, New

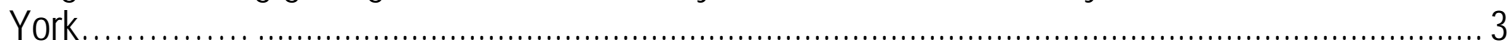

3. Graph showing gamma and geologic logs at the production test-well site in the Hoosic River valley near Hoosick Falls, New York

4. Graph showing water-level altitude in selected wells in the Hoosic River valley near Hoosick Falls, New York, February 22 through March 9, 2017 ......................................................................... 8

5. Graph showing water-level displacement associated with the pumping test in selected wells in the Hoosic River valley near Hoosick Falls, New York .............................................................. 11

6. Graphs showing water-level displacement associated with the pumping test and Theis type-curve match for selected wells in the Hoosic River valley near Hoosick Falls, New York

\section{Table}

1. Construction, field water-quality, and aquifer information for selected wells in the Hoosic River valley near Hoosick Falls, New York. 


\section{Conversion Factors}

\begin{tabular}{lcl}
\hline \multicolumn{1}{c}{ Multiply } & By & \multicolumn{1}{c}{ To obtain } \\
\hline inch (in.) & 25.4 & millimeter $(\mathrm{mm})$ \\
foot $(\mathrm{ft})$ & 0.3048 & meter $(\mathrm{m})$ \\
mile $(\mathrm{mi})$ & 1.609 & kilometer $(\mathrm{km})$ \\
gallon per minute $(\mathrm{gal} / \mathrm{min})$ & 0.06309 & liter per second $(\mathrm{L} / \mathrm{s})$ \\
foot squared per day $\left(\mathrm{ft}^{2} / \mathrm{d}\right)$ & 0.09290 & meter squared per day $\left(\mathrm{m}^{2} / \mathrm{d}\right)$ \\
\hline
\end{tabular}

\section{Datum}

Vertical coordinate information is referenced to the North American Vertical Datum of 1988 (NAVD 88). Horizontal coordinate information is referenced to the North American Datum of 1983 (NAD 83)].

Altitude, as used in this report, refers to distance above the vertical datum.

\section{Supplemental Information}

Specific conductance is given in microsiemens per centimeter at 25 degrees Celsius $\left(\mu \mathrm{S} / \mathrm{cm}\right.$ at $\left.25^{\circ} \mathrm{C}\right)$.

\section{Abbreviations}

EST eastern standard time

NYSDEC New York State Department of Environmental Conservation

PFOA perfluorooctanoic acid

USGS U.S. Geological Survey 


\title{
Groundwater-Level Analysis of Selected Wells in the Hoosic River Valley Near Hoosick Falls, New York, for Aquifer Framework and Properties
}

\author{
By John H. Williams and Paul M. Heisig
}

\begin{abstract}
The U.S. Geological Survey, in cooperation with the New York State Department of Environmental Conservation, analyzed groundwater levels, drilling record logs, and field waterquality data from selected wells, and the surficial geology in the Hoosic River valley south of the village of Hoosick Falls, New York, to provide information about the framework and properties of a confined aquifer. The aquifer, which consists of ice-contact sand and gravel overlain by lacustrine clay and silt, was evaluated by the New York State Department of Environmental Conservation as part of their investigation of alternate water supplies for the village whose wellfield has been affected by perfluorooctanoic acid. Wells inventoried in the study area were classified as confined, water table, or transitional between the two aquifer conditions. Groundwater levels in three confined-aquifer wells and a transitional-aquifer well responded to pumping of a test production well finished in the confined aquifer. Groundwater levels in a water-table well showed no detectable water-level change in response to test-well pumping. Analysis of drawdown and recovery data from the three confined-aquifer wells and a transitional-aquifer well through the application of the Theis type-curve method provided estimates of aquifer properties. Representation of a constant-head boundary in the analysis where an unnamed pond and fluvial-terrace deposits abut the valley wall resulted in satisfactory matches of the Theis type curves with the observed water-level responses. Aquifer transmissivity estimates ranged from 1,160 to 1,370 feet squared per day. Aquifer storativity estimates ranged from $5.2 \times 10^{-5}$ to $1.1 \times 10^{-3}$ and were consistent with the inferred degree of confinement and distance from the represented recharge boundary.
\end{abstract}

\section{Introduction}

The U.S. Geological Survey (USGS) in cooperation with the New York State Department of Environmental Conservation collected and analyzed groundwater levels, drilling-record logs, and field water-quality data from selected production wells in association with a pumping test of a confined aquifer in the Hoosic River valley 2 miles (mi) south of the village of Hoosick Falls, New York (fig. 1). The confined aquifer in the study area was evaluated by the NYSDEC during their investigation of alternate water supplies for the village whose wellfield has been affected by perfluorooctanoic acid (PFOA). 


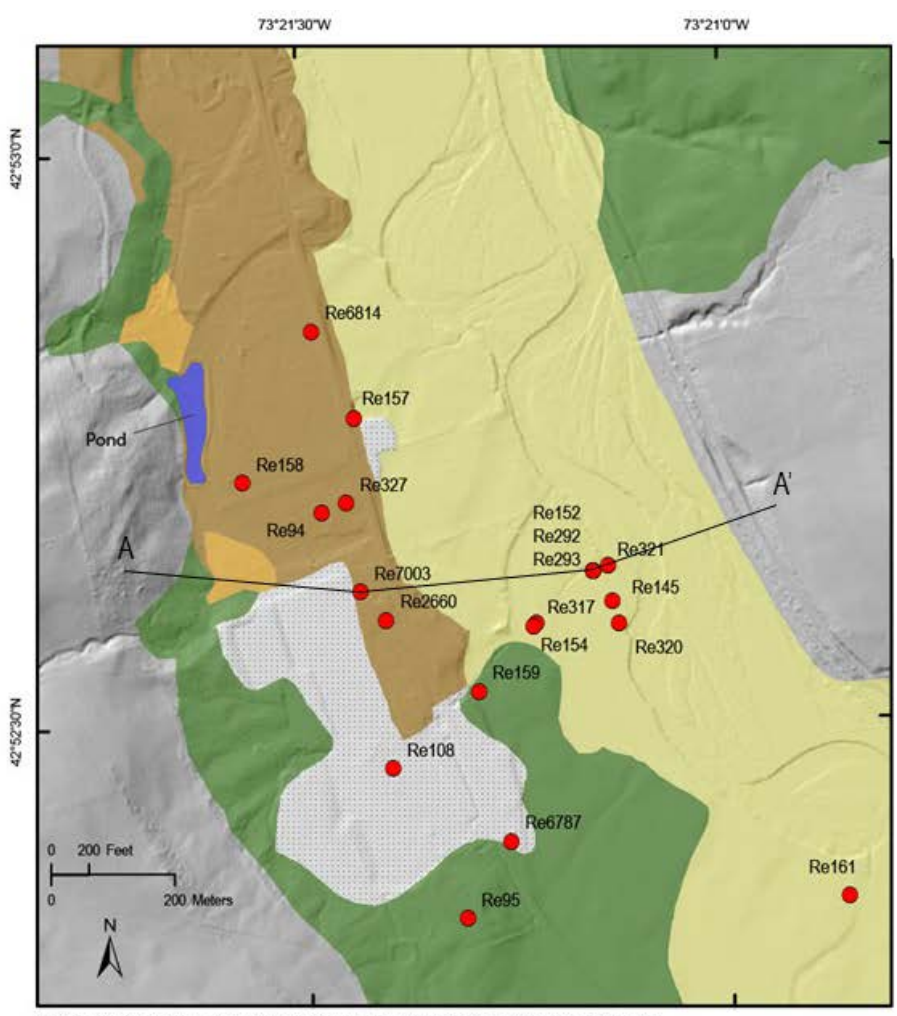

Hillshade derived from the NY State Rensselaer Hoosic River 2010 Lidar Collection

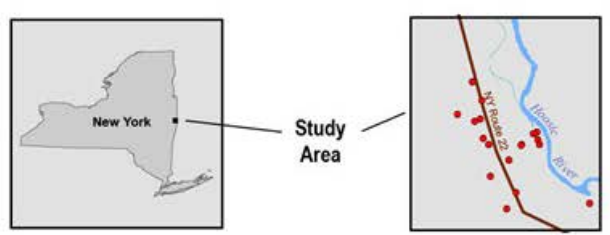

EXPLANATION

Geologic units

Artificial fill

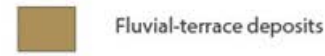

Alluvium

Lacustrine clay and silt

Alluvial-fan deposits

Re108

- Well or boring and idenffer

A $\quad A^{\prime}$ Line of geologic secfion shown in fgure 2

Figure 1. Surficial geology of the study area and location of selected wells in the Hoosic River Valley near Hoosick Falls, New York. Surficial distribution of geologic units derived from U.S. Department of Agriculture (1988) and DeSimone (2017).

The confined aquifer in the study area consists of ice-contact sand and gravel underlain by slate bedrock and overlain by lacustrine clay and silt (fig. 2). Where fractured and in hydraulic connection with the buried ice-contact sand and gravel, the uppermost bedrock forms the lower part of the confined aquifer. Most recharge to the confined aquifer probably is focused in areas where the lacustrine clay and silt are thin or absent as a result of fluvial erosion.

Saturated alluvium on the valley bottom and fluvial-terrace and alluvial-fan deposits near the valley wall form a water-table (unconfined) aquifer in hydraulic contact with the till-bedrock uplands and surface water. 


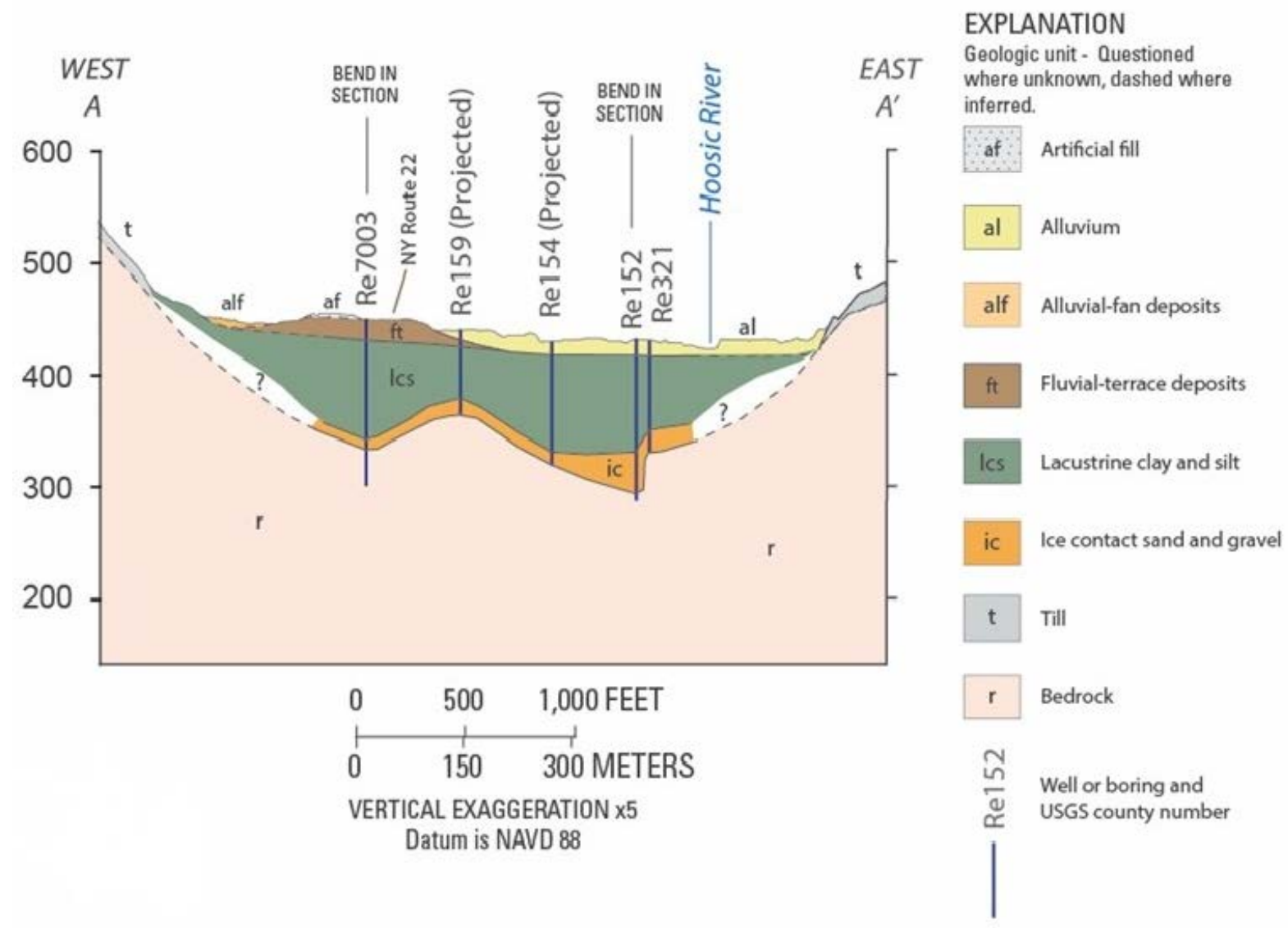

Figure 2. Geologic section of the study area in the Hoosic River valley near Hoosick Falls, New York. Line of section shown in figure 1.

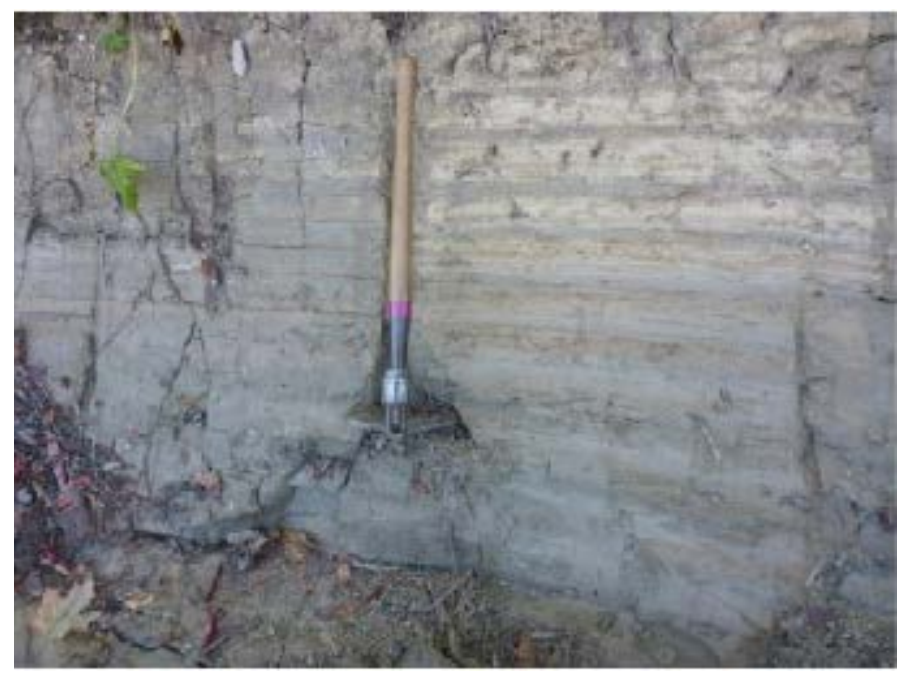

Lacustrine clay and silt exposed 0.3 mile northwest of the study area in the Hoosic River valley near Hoosick Falls, New York; photograph courtesy of David J. DeSimone, DeSimone Geoscience Investigations. 
The drilling site for production test well Re293 was selected by the NYSDEC and their consultant on the basis of results from test borings (fig. 1; table 1) and surface geophysical surveys (Arcadis CE, Inc., 2017). More than 35 feet (ft) of ice-contact sand and gravel, confined by $80 \mathrm{ft}$ of lacustrine clay and silt, was penetrated at the site selected for the production test well (fig. 3). Production test well Re293 was finished with a natural gravel-pack screen in the confined sand and gravel aquifer from 118 to $138 \mathrm{ft}$ below land surface. Observation wells Re145, Re152, Re154, Re159, and Re161 were finished with a 10-ft-long screen in the confined sand and gravel aquifer (fig. 1; table 1). Observation well Re292 was finished as an open hole in the uppermost bedrock. The production test well was pumped at a constant rate of 300 gallons per minute (gal $/ \mathrm{min}$ ) for 72 hours starting at 5:50 p.m. eastern standard time (EST) on March 3, 2017, and ending at 5:50 p.m. EST on March 6, 2017. Groundwater levels in the production test wells and the observation wells were collected and analyzed for aquifer properties by the consultant (Arcadis CE, Inc., 2017).

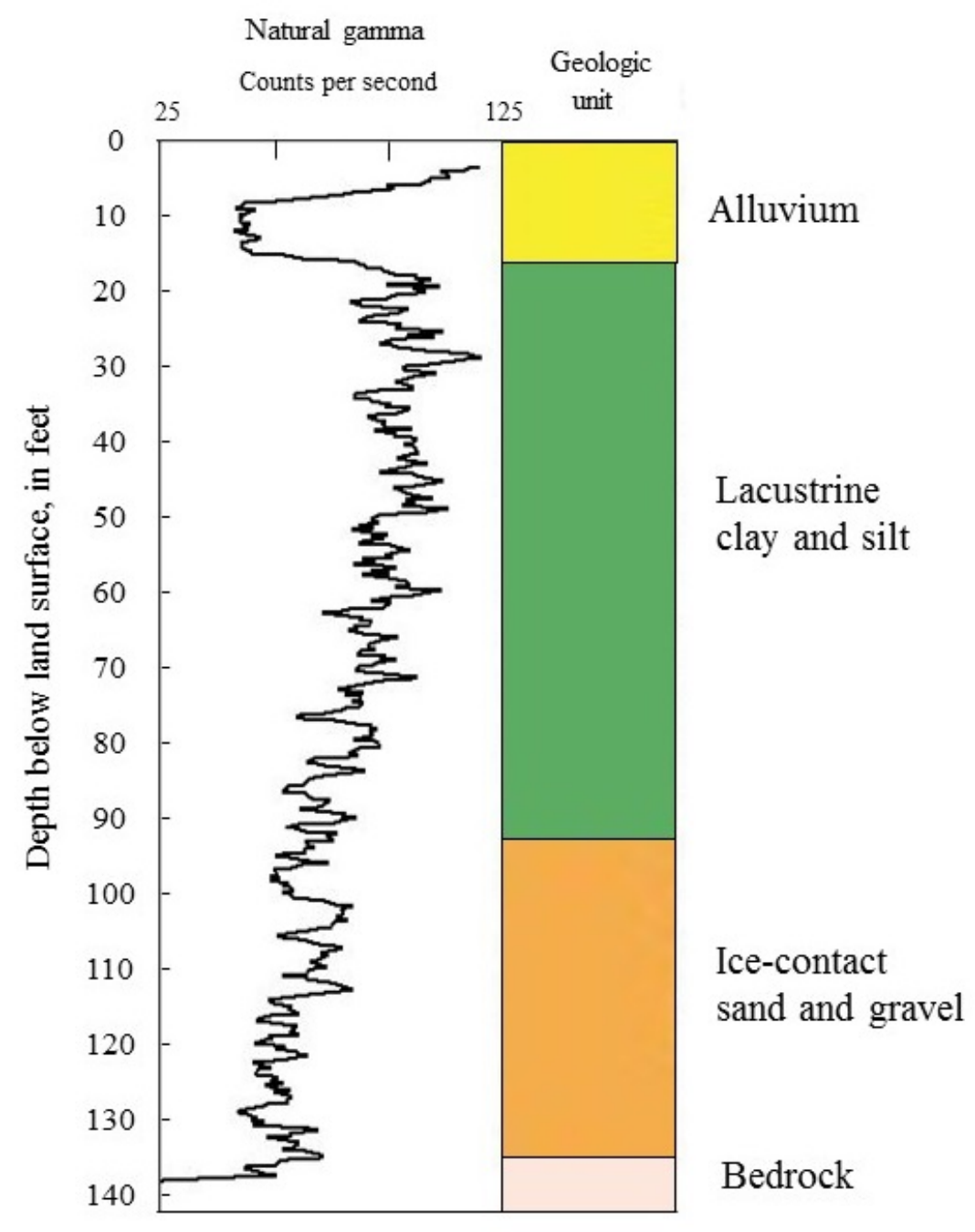

Figure 3. Gamma and geologic logs at the production test-well site in the Hoosic River valley near Hoosick Falls, New York. 


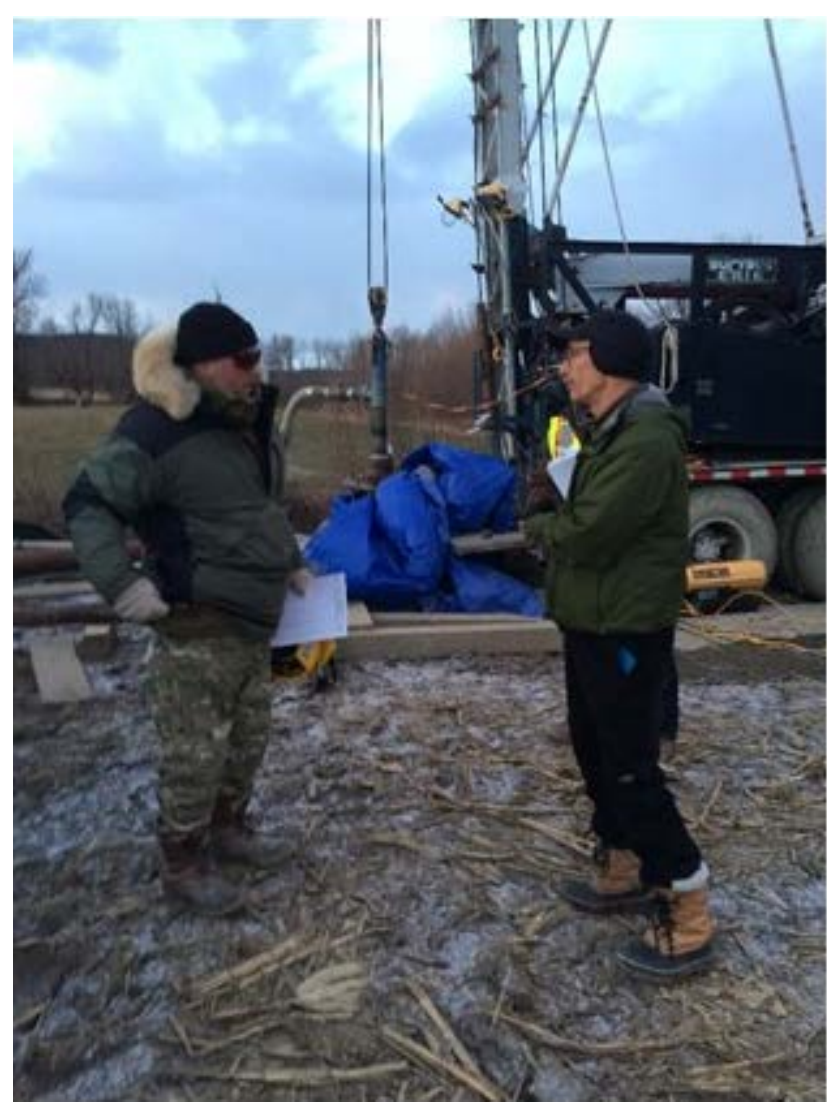

A U.S. Geological Survey hydrologist and an Arcadis CE, Inc. consultant discuss coordination of the pumping test for the production test well; photograph by John H. Williams, U.S. Geological Survey. 
Table 1. Construction, field water-quality, and aquifer information for selected wells in the Hoosic River valley near Hoosick Falls, New York.

[All depths are below land surface. Use: C, commercial; R, residential; S, school; O, observation; E, exploration; T, test. USGS, U.S. Geological Survey; ID, identification number; NWIS, National Water Information System; Arcadis, Arcadis CE, Inc.; ft, foot; NAVD 88, North American Vertical Datum of 1988; in., inch; SC, specific conductance; $\mu \mathrm{S} / \mathrm{cm}$, microsiemens per centimeter at 25 degrees Celsius; - , not measured or not reported]

\begin{tabular}{|c|c|c|c|c|c|c|c|c|c|c|c|c|}
\hline $\begin{array}{l}\text { USGS well } \\
\text { ID }\end{array}$ & NWIS ID & $\begin{array}{c}\text { Arcadis site } \\
\text { ID }\end{array}$ & Use & $\begin{array}{c}\text { Altitude, in } \\
\mathrm{ft} \text { above } \\
\text { NAVD } 88\end{array}$ & $\begin{array}{l}\text { Year } \\
\text { drilled }\end{array}$ & $\begin{array}{l}\text { Hole } \\
\text { depth, } \\
\text { in } \mathrm{ft}\end{array}$ & $\begin{array}{l}\text { Casing } \\
\text { depth, } \\
\text { in } \mathrm{ft}\end{array}$ & $\begin{array}{l}\text { Casing } \\
\text { diameter, } \\
\text { in in. }\end{array}$ & Finish type & $\begin{array}{l}\text { Field SC, } \\
\text { in } \mu S / \mathrm{cm}\end{array}$ & $\begin{array}{l}\text { Field } \\
\mathrm{pH}\end{array}$ & Aquifer type \\
\hline Re94 & 425238073213401 & - & $\mathrm{R}$ & 450 & - & 126 & 126 & 6 & Open end & - & - & Confined \\
\hline Re95 & 425217073212701 & - & $\mathrm{R}$ & 465 & - & 102 & 90 & 6 & Open hole & - & - & Confined \\
\hline Re108 & 425227073212401 & - & $\mathrm{S}$ & 455.11 & 1960 & 132 & - & 8 & 一 & 396 & 7.4 & Confined \\
\hline Re145 & 425236073210801 & OBS-01 & $\mathrm{O}$ & 431.16 & 2016 & 110 & 100 & 1.25 & Screen & - & - & Confined \\
\hline Re152 & 425237073210901 & OBS-02 & $\mathrm{O}$ & 430.22 & 2016 & 131 & 121 & 1.25 & Screen & - & - & Confined \\
\hline Re154 & 425235073211301 & OBS-03 & $\mathrm{O}$ & 430.92 & 2016 & 110 & 100 & 1.25 & Screen & - & - & Confined \\
\hline Re157 & 425246073212601 & - & $\mathrm{C}$ & 434.49 & - & 8 & 8 & 36 & Dug & 597 & 6.5 & Water table \\
\hline Re158 & 425242073213401 & - & $\mathrm{R}$ & 442.83 & - & 87 & 一 & 6 & - & 333 & 6.8 & Transitional \\
\hline Re159 & 425231073211701 & OBS-04 & $\mathrm{O}$ & 435.65 & 2016 & 80 & 70 & 1.25 & Screen & - & - & Confined \\
\hline Re161 & 425220073205101 & OBS-05 & $\mathrm{O}$ & 434.26 & 2016 & 145 & 135 & 1.25 & Screen & - & - & Confined \\
\hline Re292 & 425237073210902 & OBS-BR & $\mathrm{O}$ & 430.2 & 2016 & 143 & 138 & 6 & Open hole & - & - & Confined \\
\hline $\operatorname{Re} 293$ & 425237073210903 & PW-01 & $\mathrm{T}$ & 430.2 & 2017 & 138 & 118 & 10 & Screen & 695 & 7.6 & Confined \\
\hline $\operatorname{Re} 317$ & 425235073211401 & Loc4 SB-01 & $\mathrm{E}$ & 432 & 2016 & 113 & - & - & Boring & - & - & - \\
\hline Re320 & 425235073210701 & Loc4 SB-02 & $\mathrm{E}$ & 437 & 2016 & 119 & 一 & 一 & Boring & - & - & - \\
\hline Re321 & 425238073210801 & Loc4 SB-03 & $\mathrm{E}$ & 435 & 2016 & 102 & - & - & Boring & - & - & - \\
\hline Re327 & 425241073212701 & - & $\mathrm{R}$ & 445 & - & - & - & - & Well point & 263 & 6.4 & Water table \\
\hline Re2660 & 425235073212401 & - & $\mathrm{R}$ & 450 & 2004 & 305 & 134 & 6 & Open hole & - & - & Confined \\
\hline Re6787 & 425223073211501 & - & $\mathrm{R}$ & 445 & 2013 & 200 & 72 & 6 & Open hole & 367 & 7.6 & Confined \\
\hline Re6814 & 425250073212901 & - & $\mathrm{C}$ & 442.22 & 2012 & 84 & 80 & 6 & Screen & 451 & 7.0 & Confined \\
\hline Re7003 & 425237073212601 & - & $\mathrm{C}$ & 449.93 & 2013 & 150 & 117 & 6 & Open hole & 450 & 7.4 & Confined \\
\hline
\end{tabular}




\section{Well Inventory and Field Water Quality}

The USGS inventoried wells in the study area to provide additional aquifer framework information and expand the groundwater-level monitoring network for the pumping test. The inventoried wells included residential wells Re94, Re95, Re158, Re327, Re2660, and Re6787; commercial wells Re157, Re6814, and Re7003; and Hoosick Falls High School well Re108 (fig. 1; table 1). Drilling-record logs indicated that wells Re94, Re95, Re2660, Re6787, and Re7003 were finished in ice-contact sand and gravel and (or) fractured bedrock, confined by 60 to $120 \mathrm{ft}$ of lacustrine clay and silt. Although no log was available for well Re108, it is likely that this well also was finished in ice-contact sand and gravel and (or) fractured bedrock confined by thick lacustrine clay and silt. Well Re6814 was finished in sand and gravel, confined by more than $50 \mathrm{ft}$ of hardpan. Dug well Re157 and well point Re327 were finished in unconfined fluvialterrace deposits, which are underlain by lacustrine clay and silt. The bottom of well Re158 was sounded at a depth of $87 \mathrm{ft}$ below land surface, but no information was available concerning the depth of casing or type of finish.

The USGS sampled groundwater from wells Re108, Re157, Re158, Re293, Re327, Re6787, Re6814, and Re7003 for field measurement of $\mathrm{pH}$ and specific conductance (fig. 1; table 1). In groundwater flow systems not dominated by carbonate rocks and not affected by human activities, young unconfined groundwater is characterized by low $\mathrm{pH}$ and low dissolved mineral content (specific conductance) that gradually increase with residence time in the flow system, especially as the groundwater becomes isolated from the atmosphere under confined conditions.

The $\mathrm{pH}$ of shallow groundwater sampled from water-table aquifer wells Re327 and Re157 was 6.4 and 6.5, respectively. The $\mathrm{pH}$ of groundwater near the valley wall sampled from confined-aquifer wells Re108, Re7003, and Re6814 was between 7.0 and 7.4. The pH of groundwater farther from the valley wall sampled from confined-aquifer wells Re293 and Re6787 was 7.6. At well Re158 where the aquifer is believed to be transitional between watertable and confined conditions, the sampled groundwater was transitional, having a $\mathrm{pH}$ of 6.8.

The specific conductance of groundwater showed a similar trend when shallow groundwater near and downgradient of State Route 22 was excluded because highway deicing salt substantially increased the specific conductance of the groundwater. The specific conductance of shallow groundwater upgradient of State Route 22 sampled from well Re327 was 263 microsiemens per centimeter at 25 degrees Celsius $(\mu \mathrm{S} / \mathrm{cm})$. The specific conductance of groundwater from the confined-aquifer conditions was between 396 and $451 \mu \mathrm{S} / \mathrm{cm}$ near the valley wall and between 367 and $695 \mu \mathrm{S} / \mathrm{cm}$ away from the valley wall. The specific conductance under transitional-aquifer conditions was also transitional $(333 \mu \mathrm{S} / \mathrm{cm})$.

\section{Groundwater-Level Data Collection}

In association with the pumping test and in cooperation with NYSDEC and their consultant, the USGS monitored water levels in wells Re108, Re157, Re158, Re6814, and Re7003 (fig. 1; table 1) from February 22 through March 9, 2017. The groundwater levels were recorded at 1-minute intervals using submersible nonvented pressure transducers (Freeman and others, 2004) whose pressure measurements were compensated for changes in barometric pressure based on readings from a barometric-pressure transducer installed in vented well Re7003, and converted to depth in feet below the measuring point based on manual measurements with an electric water-level tape at the time of installation and removal of the 
instrumentation. The well measuring points were surveyed (Arcadis CE, Inc., 2017) in order to convert the water-level depths to water-level altitudes. Additional manual water-level measurements were made in the wells using a hand-held acoustic device before the start, during the early part, and near the end of test well pumping.

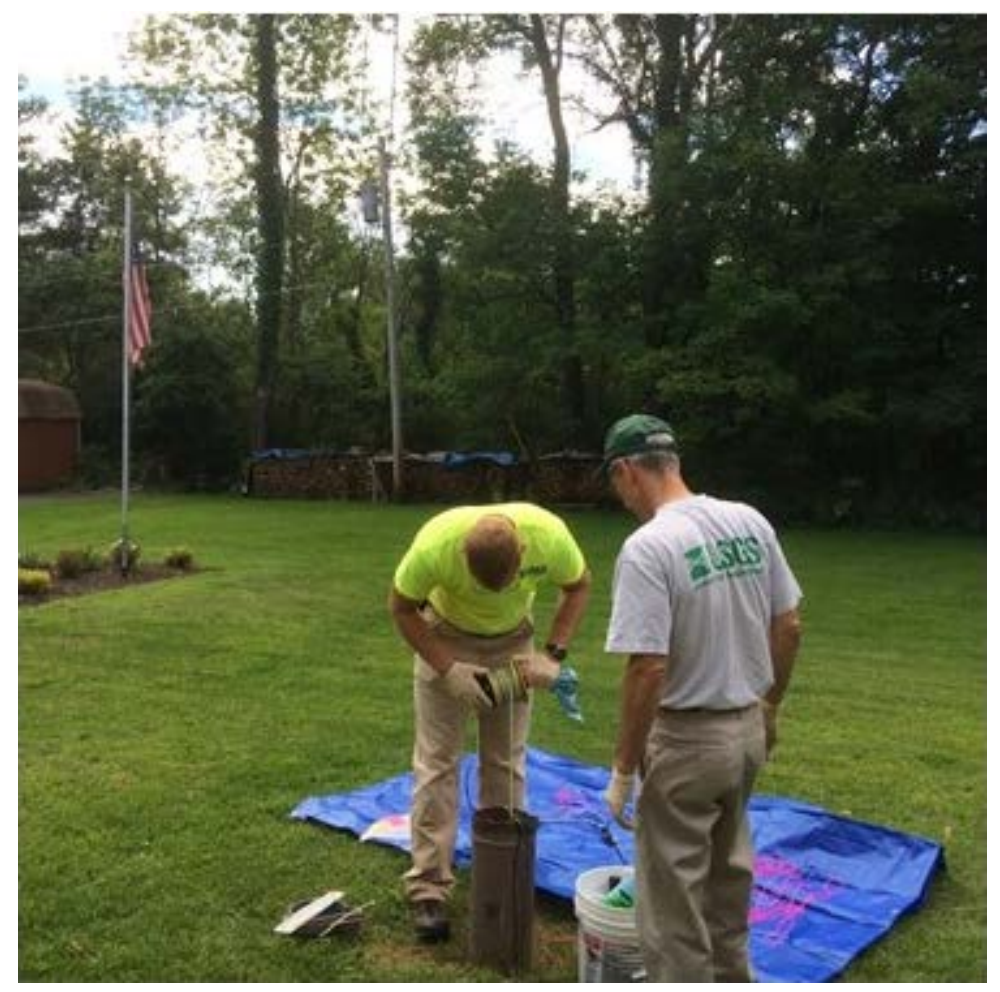

U.S. Geological Survey hydrologists collecting a manual water-level measurement at a residential well in the Hoosic River Valley near Hoosick Falls, New York; photograph by John H. Williams, U.S. Geological Survey.

\section{Groundwater-Level Analysis for Aquifer Framework}

The groundwater-level monitoring period included a rise and fall of water levels related to aquifer recharge from precipitation on February 25, quasistabilization of water levels before the start of the pumping test on March 3, drawdown related to the 72-hour period of controlled pumping from the production test well, and 65-hour period of water-level recovery following cessation of test-well pumping (fig. 4).

Ambient water levels in wells Re108, Re6814, and Re7003 reflected the hydraulic head in the confined aquifer and that in well Re157 reflected the position of the water table. Based on the difference between these two sets of measurements, the head in the confined aquifer was about 10 feet lower than the water table during the monitoring period. Water levels in well Re158 were transitional between those of the confined and water-table aquifers. 


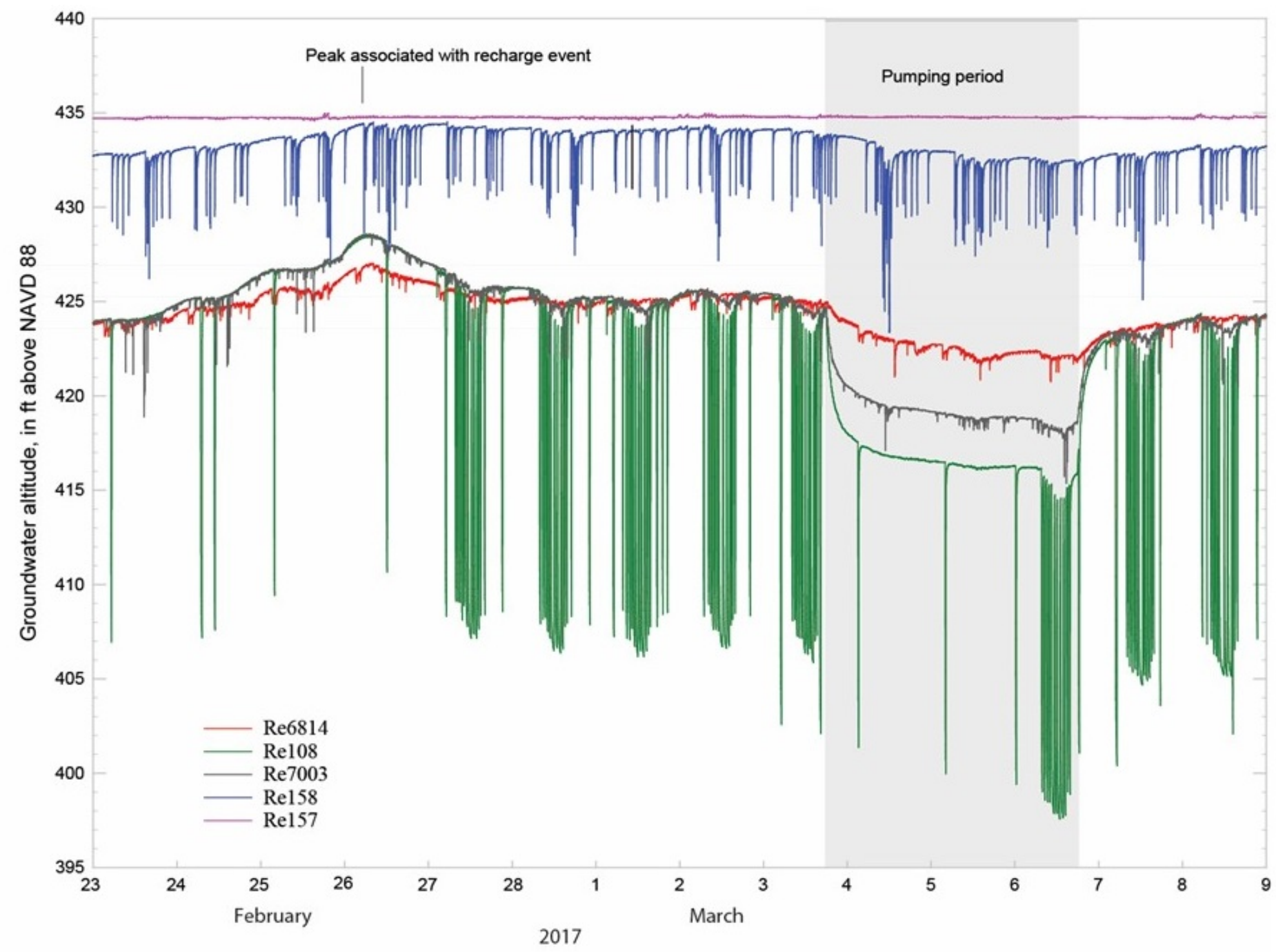

Figure 4. Water-level altitude in selected wells in the Hoosic River Valley near Hoosick Falls, New York, from February 22 through March 9, 2017. Water-level data are available from the U.S. Geological Survey (2017). 
Water levels in confined-aquifer well Re108 fluctuated by more than $15 \mathrm{ft}$, owing to periodic pumping of the well at a rate of $30 \mathrm{gal} / \mathrm{min}$ for school use (fig. 4). Water levels in the well affected by single pump on-off cycles rapidly recovered back to ambient conditions. Closely spaced cycles of pumping lasting up to 10 hours did not allow for complete water-level recovery during the periods of high water demand. Water levels in confined-aquifer wells Re6814 and Re7003 fluctuated by about $1 \mathrm{ft}$ because of infrequent, low-rate pumping of short duration for commercial use during business hours. Water levels in well Re7003 were also affected by the cyclic pumping of well Re108, indicating a good hydraulic connection between these wells located $955 \mathrm{ft}$ apart. Water levels in transitional-aquifer well Re108 fluctuated by 3 to $5 \mathrm{ft}$, because of frequent, low-rate pumping of short duration for domestic use. Water levels in watertable well Re157 fluctuated by less than $0.1 \mathrm{ft}$ because of very infrequent and very low-rate pumping of short duration for commercial use during business hours.

Recharge on February 25 caused a sharper rise and fall in water levels in confined-aquifer wells Re108, Re6814, and Re7003 than in wells Re157 and Re158 (fig. 4). Reported precipitation on this date at the Bennington Morse Airport meteorological station, $8 \mathrm{mi}$ east of Hoosick Falls, was 0.65 inch. The water-level change was about $1 \mathrm{ft}$ in wells Re108 and Re7003, the most change in all the wells, indicating the greatest degree of confinement of the monitored wells. Water levels in transitional-aquifer well Re158 displayed a lesser and broader rise and fall from the recharge event than those of the confined-aquifer wells. With the water table above land surface in the surrounding low-lying area, water levels in water-table aquifer well Re157 showed little response to the recharge event, rising less than $0.1 \mathrm{ft}$.

During the pumping test of production test well Re293, an attempt was made to minimize the pumping from well Re108, and during the first 60 hours of the test, pumping from well Re108 was limited to three on-off pump cycles (fig. 5). Three periods of closely spaced cycles of pumping from well Re108 occurred during the latter part of the pumping test and during recovery.

The most rapid and largest magnitude water-level response in all the wells monitored by the USGS during the pumping test was in confined-aquifer well Re108, which indicates that the greatest degree of hydraulic connection and confinement are between this well and the pumped production test well Re293 (fig. 5). After 60 hours of pumping, drawdown in well Re108, which was 1,490 ft from the test well, reached $8.4 \mathrm{ft}$. Drawdown in confined-aquifer well Re7003, which was 1,240 ft away from the test well, reached $6.0 \mathrm{ft}$. The water-level response in confinedaquifer well Re6814 was more subdued than in the other confined-aquifer wells, reaching $2.5 \mathrm{ft}$, reflecting the greater distance from the pumped well $(1,955 \mathrm{ft})$ and a lesser hydraulic connection and (or) lesser degree of confinement. Although about the same distance from the pumped well, the water-level response in transitional-aquifer well Re158 lagged 5 hours behind and was even more subdued (1.2 ft of drawdown) than that of well Re6814, indicating less confinement and potentially greater degree of hydraulic connection with the water-table aquifer. Water levels in water-table aquifer well Re157 showed no detectable change in response to pumping of the production test well. 


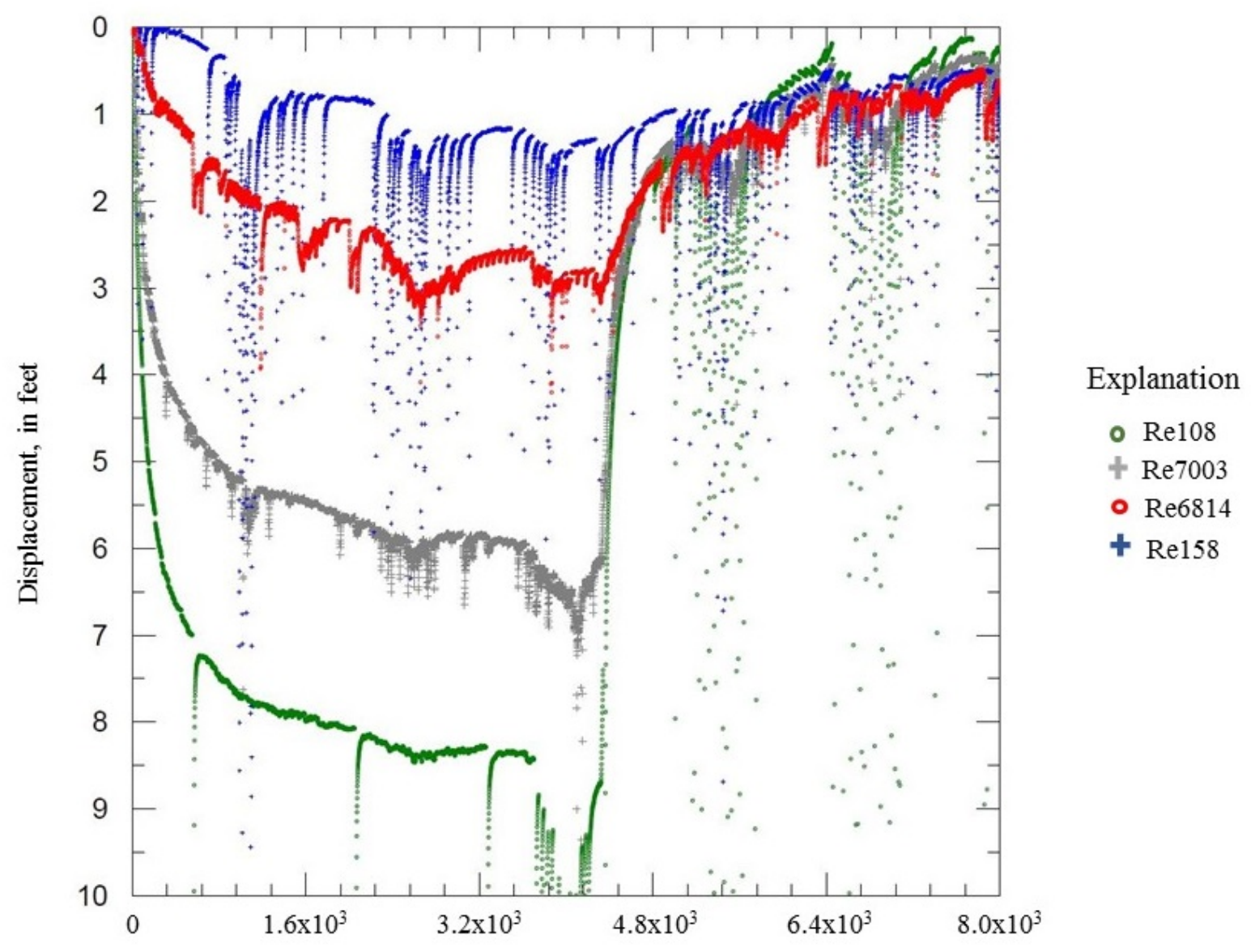

Elapsed time, in minutes

Figure 5. Water-level displacement (drawdown and recovery) associated with the pumping test in selected wells in the Hoosic River valley near Hoosick Falls, New York.

\section{Groundwater-Level Analysis for Aquifer Properties}

The analytical solution of Theis (1935) for a pumping test in a confined aquifer was used for the quantitative analysis of the groundwater-level data. The following idealized aquifer and well conditions are assumed in the application of this analytical solution: the aquifer is confined, has infinite areal extent and uniform thickness, and is homogeneous and isotropic; pumping and observation wells are fully penetrating; flow is radial to the pumping well; flow is unsteady, and water is released instantaneously from storage with decline in hydraulic head; and storage in the pumping well is negligible.

The aquifer properties of transmissivity and storativity were estimated from the Theis type-curve analysis through the use of the computer program of Duffield (2007). The computer program uses the principle of superposition (Streltsova, 1988) to simulate drawdown and recovery during variable-rate pumping tests in multiple wells, allows for representation of boundary conditions through the application of image-well theory (Ferris and others, 1962), and performs nonlinear least-squares parameter estimation for automatic type-curve matching. 
The displacement datasets for wells Re108, Re158, Re6814, and Re7003 during the pumping and recovery of production test well Re293 were analyzed. A constant pumping rate of $300 \mathrm{gal} / \mathrm{min}$ from the production test well during a 72-hour period was represented in the analysis. In addition, three periods of closely spaced pumping cycles in well Re108, one beginning 62 hours into the pumping test and two occurring during recovery were included in the analysis. The estimated average pumping rate from well Re108 was 15 gal/min for these periods, which lasted from 7.7 to 10.6 hours. Pumped flow-rate data for wells Re293 and Re108 used in the type-curve match analysis are available from the U.S. Geological Survey (2017). Water-level changes associated with individual pumping cycles in each of the wells are included in the observations but were not used in the analysis.

The early water-level displacement data from wells Re108 and Re7003 were satisfactorily matched with Theis type curves with no changes in aquifer type or boundary conditions. The subsequent displacement data, however, diverged from Theis type curves suggesting a leaky confined aquifer and (or) a recharge boundary. The water-level displacement data from well Re6814 were not satisfactorily matched with the Theis type curves, indicating divergence from idealized aquifer and (or) boundary conditions. The early water-level displacement data from well Re158, which displayed a delayed response to pumping, diverted substantially from Theis type curves, suggesting the probable presence of a nearby recharge boundary.

Given the known and inferred distribution of the confining unit and the observed waterlevel responses and their divergence from Theis type curves, a constant-head boundary was represented in the analysis using image-well theory. The constant-head boundary was located just west of well Re158, where an unnamed pond and the fluvial-terrace deposits abut the valley wall. Representing this surface-water feature as a recharge boundary resulted in satisfactory matches of the observed water-level responses with the resulting Theis type curves and provided reasonable, consistent estimates of aquifer properties for wells Re108, Re158, Re6814, and Re7003 (fig. 6).

The estimated aquifer transmissivity for wells Re108, Re158, Re6814, and Re7003 ranged from 1,160 to 1,370 feet squared per day ( $\mathrm{ft}^{2} / \mathrm{d}$ ) and averaged $1,290 \mathrm{ft}^{2} / \mathrm{d}$. The highest transmissivity estimates were for wells Re7003 and Re158, and the lowest was for well Re108. Given the differences in the completion of construction among the wells and the known departures from idealized aquifer and boundary conditions, the estimated transmissivity values are remarkably close, and the differences between them are not deemed substantial. The estimated aquifer storativity ranged over two orders of magnitude. The storativity estimates progressively increased consistently with the inferred reduction in the degree of confinement and distance from the represented recharge boundary. The lowest storativity, $5.2 \times 10^{-5}$, was estimated for well Re108. The highest storativity, $1.1 \times 10^{-3}$, was estimated for well Re158. The storativity estimates for wells Re7003 and Re6814 were $1.4 \times 10^{-4}$ and $3.7 \times 10^{-4}$, respectively. 
A. $\operatorname{Re} 108$

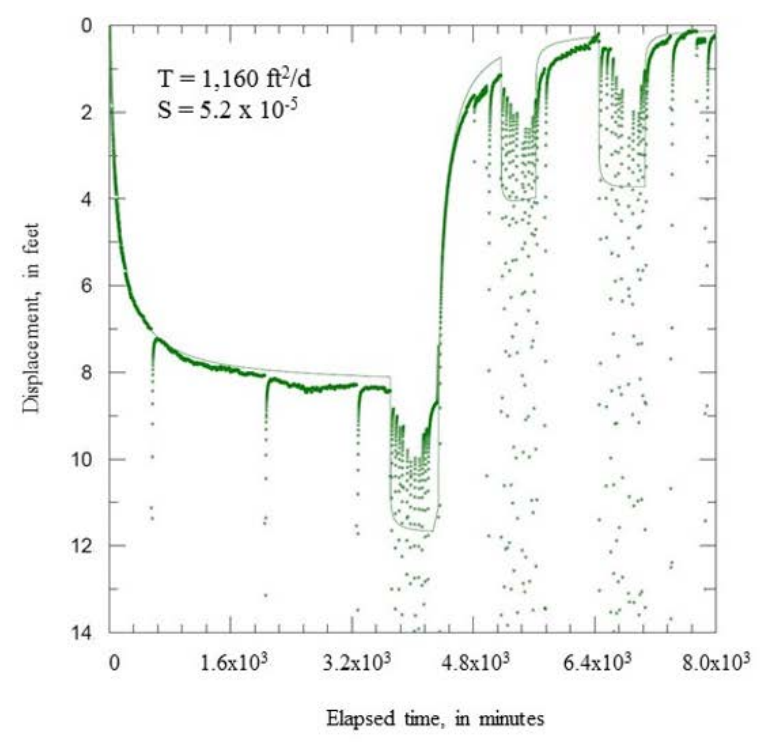

C. $\operatorname{Re} 6814$

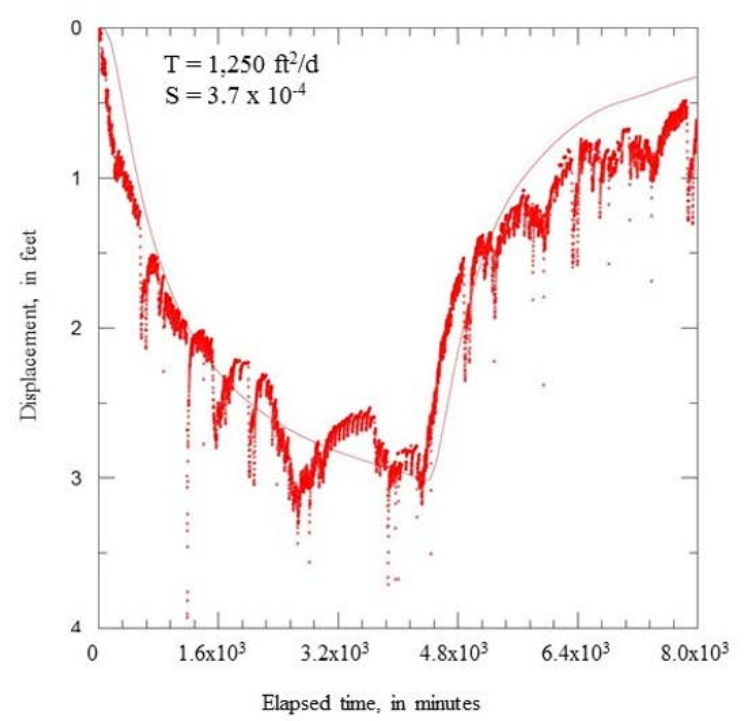

B. $\operatorname{Re} 7003$

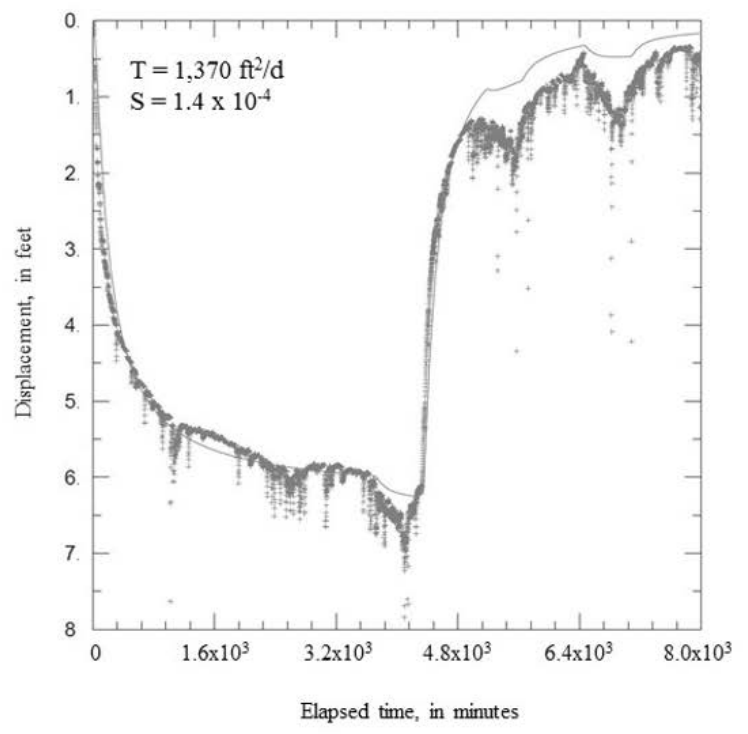

D. $\operatorname{Re} 158$

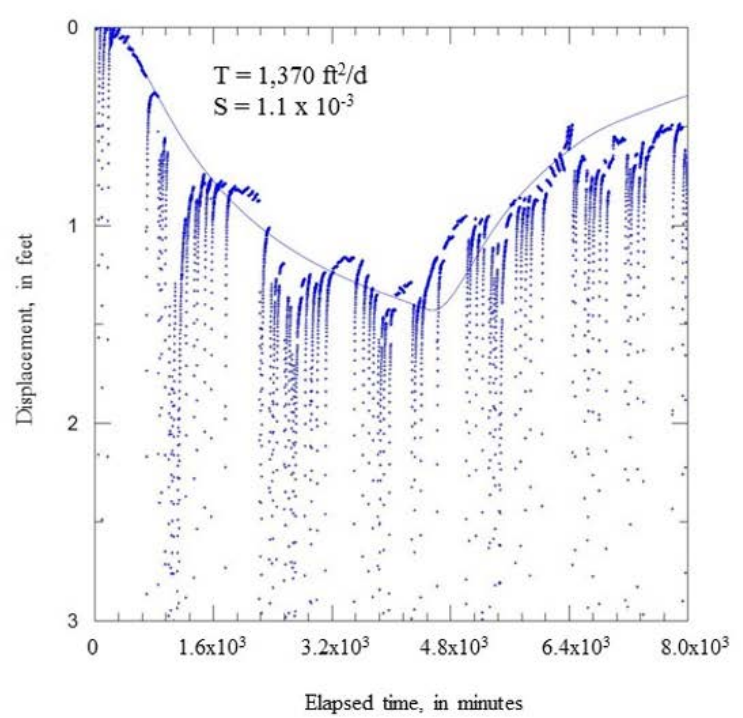

Figure 6. Water-level displacement (drawdown and recovery) associated with the pumping test and Theis type-curve match using image-well theory for wells $A, \operatorname{Re108,~B,~Re7003,~C,~Re6814,~and~D,~Re158~in~the~}$ Hoosic River valley near Hoosick Falls, New York. Estimated transmissivity (T) and storativity (S) are shown for each well. 


\section{Summary}

An integrated analysis by the U.S. Geological Survey of water levels, drilling-record logs, and field water quality from wells along with the surficial geology provided insights into the framework of the confined aquifer in the Hoosic River valley near Hoosick Falls, New York. The inventoried wells were classified as confined, unconfined, or transitional between the two aquifer conditions. Theis type-curve analysis of drawdown and recovery data from the selected wells during pumping of a production test well provided estimates of aquifer properties. Representation of a constant-head boundary in the analysis where an unnamed pond and the fluvial-terrace deposits abut the valley wall yielded satisfactory matches of the Theis type curves with the observed water-level responses and reasonable estimates of aquifer properties. Aquifer transmissivity estimates for the wells were very similar, ranging from 1,160 to 1,370 feet squared per day. Aquifer storativity estimates ranged from $5.2 \times 10^{-5}$ to $1.1 \times 10^{-3}$ and were consistent with the inferred degree of confinement and distance from the represented recharge boundary.

\section{References Cited}

Arcadis CE, Inc., 2017, Groundwater source aquifer evaluation-Hoosick Falls alternate water supply study: New York State Department of Environmental Conservation, 26 p., 5 appendixes.

DeSimone, D.J., 2017, Surficial geology of Hoosick Falls, New York: Hoosick Falls Central School District, 1:12,000 scale, 31 p., accessed March 15, 2017, at http://www.hoosickfallscsd.org/hoosick-area-hydrogeology-groundwater-research-data/.

Duffield, G.M., 2007, AQTESOLV for Windows; version 4.5; user’s guide: Reston, Va., HydroSOLVE, Inc., 529 p.

Ferris, J.G., Knowles, D.B., Brown, R.H., and Stallman, R.W., 1962, Theory of aquifer tests:

U.S. Geological Survey Water-Supply Paper 1536-E, 174 p. [Also available at https://pubs.er.usgs.gov/publication/wsp1536E.]

Freeman, L.A., Carpenter, M.C., Rosenberry, D.O., Rousseau, J.P., Unger, Randy, and McLean, J.S., 2004, Use of submersible pressure transducers in water-resources investigations: U.S. Geological Survey Techniques of Water-Resources Investigations, book 8, chap. A3, 50 p. [Also available at https://pubs.er.usgs.gov/publication/twri08A3.]

Streltsova, T.D., 1988, Well testing in heterogeneous formations: New York, John Wiley \& Sons, Inc., 413 p.

Theis, C.V., 1935, The relation between the lowering of the piezometric surface and the rate and duration of discharge of a wells using groundwater storage: Eos, Transactions, American Geophysical Union, v. 16, p. 519-524.

U.S. Department of Agriculture, 1988, Soil survey geographic (SSURGO) database for Rensselaer County, New York: U.S. Department of Agriculture soil data, accessed March 15, 2016, at https://sdmdataaccess.nrcs.usda.gov/.

U.S. Geological Survey, 2017, USGS water data for the Nation: U.S. Geological Survey National Water Information System database, accessed October 23, 2017 at https://doi.org/10.5066/F7P55KJN. 